\title{
Correction to: The Impact of Religiosity on Substance Abuse and Obesity in African Americans
}

\author{
Bernice A. Dodor ${ }^{1} \cdot$ Michael A. Robinson $^{2}$ (ID $\cdot$ Reed Watson $^{1}$. \\ David Meetze $^{3} \cdot$ Ronald Whicker $\mathrm{Jr}^{3}$
}

Published online: 10 November 2017

(C) Springer Science+Business Media, LLC 2017

\section{Correction to: J Relig Health https://doi.org/10.1007/s10943-017-0501-2}

The original version of this article unfortunately contained a mistake in the author names. The co-author names should be David Meetze and Ronald Whicker Jr. instead of David Meetz and Ronald Wicker.

The original article has been corrected.

The original article can be found online at https://doi.org/10.1007/s10943-017-0501-2.

Michael A. Robinson

marobi01@uga.edu

Bernice A. Dodor

dodorb@ecu.edu

Reed Watson

watsonr14@students.ecu.edu

David Meetze

davidneilmeetze@gmail.com

Ronald Whicker Jr.

ronniewhicker@gmail.com

1 Department of Human Development and Family Science, East Carolina University, 128 Rivers Building, Greenville, NC 27858, USA

2 School of Social Work, University of Georgia, 279 Williams Street, Athens, GA 30602, USA

3 School of Social Work, East Carolina University, Greenville, NC 27858, USA 